\title{
Nutritional and Health Implications of Conventional Agriculture - A review
}

\section{Habte $\mathrm{TY}^{*}$ and Krawinkel M}

Nutrition in Developing Countries, Institute of Human Nutrition, Justus-Liebig-University Giessen, Giessen, Germany

*Corresponding author: Habte TY, Nutrition in Developing Countries, Wilhelmstrasse 20, 35392 Giessen, Germany, E-mail: Tsige-Yohannes.Habte@ernaehrung.uni-giessen.de

Citation: Habte TY, Krawinkel M (2015) Nutritional and Health Implications of Conventional Agriculture A review. J Nutr Health Sci 2(1): 106. doi: 10.15744/2393-9060.1.406

Received Date: January 22, 2015 Accepted Date: February 20, 2015 Published Date: February 25, 2015

\begin{abstract}
The ecosystem imbalance imposed by conventional agriculture is characterized by the loss of biodiversity that leads to uneven biological-energy distribution or to the disequilibrium of photosynthesis and respiration. These changes contribute to the excessive greenhouse gas accumulation in the atmosphere followed by global climate change. The loss of biodiversity and the technologies applied in conventional agriculture are additionally involved in the depletion and adulteration of fertile soils and living water systems. The changes in the ecosystem are further implicated in nutrition security and human health problems. Energy-dense diets with low diversity and increasing meat consumption become more frequent. As a result, overweight, and the deficiency of micronutrients and essential phytochemicals with respective health consequences are widespread. Both the environmental and nutritional changes influenced the global human health by increasing the prevalence of diabetes mellitus, anemia, xerophthalmia, cardiovascular problems, the risk of cancer and abnormal growth. At the same time, the risks of respiratory and reproductive problems as well as vector transmitted infectious diseases become more common. The problems and the contexts of tackling the challenges are so complex that some simple tailor-made solutions are unlikely to function. Two-system approach considering globally important issues on one part and regionally or locally more impacting issues on the other part when designed and applied simultaneously appear to be promising. The global approach can deal with green-house-gas emission and climate change, whereas regional and local approach can consider the local problems of soil and water depletion and pollution, as well as the degradation of biodiversity with special attention to its function as carbon dioxide sink and essential micronutrient supplier.
\end{abstract}

Keywords: Conventional agriculture; Ecosystem imbalance; Malnutrition; Health problems, Two-system approach

\section{Introduction}

Since the middle of the $20^{\text {th }}$ century, conventional agriculture has expanded to tackle human hunger, which was ubiquitous in South America, Africa, South Asia and some parts in Europe. Natural vegetation is cleared to grow high yielding food crops, which express their potential with the application of agrochemicals and irrigation systems. Agricultural diversity is replaced by homogenous production systems that simplify cultural practices and increase labour efficiency. In the years between 1961 and 2005 the global crop production increased by 167\%, from 1.8 to 4.8 billion tons while global crop land increased only by $27 \%$ [1]. In view of the change of global crop productivity from 1.84 to 3.96 t/ha [2], the gain is largely attributed to agricultural intensification which in essence characterises conventional agriculture.

Following the intensification and expansion of the modern practices the rule of nature which is diverse and self-regulating has been overtaken by conventional agriculture which is homogenous and artificially controlled. Conventional agriculture is primarily endowed with yield maximisation, giving little attention to the ecosystem balance and its services. The neglect of the ecosystem balance compromises the sustainability of food production, nutrition security and public health. It is the purpose of this review to reflect some of these effects so that they get due attention and priority in policy planning targeted at sustainable and healthy food production.

\section{Environmental implication}

Conventional agriculture is characterized by the production of high yielding, and specialized food crops that express their potential when supplemented with inorganic fertilizers and protected with pesticides. The inorganic fertilizers are produced by employing fossil fuel, the resources additionally used to distribute them and the harvested crops around the world. A good proportion (35\%) of the harvested crop is fed to livestock, which are inefficient converters of the food energy to animal products [3]. The cumulative side effects of homogenization, chemical fertilization, fossil fuel burning to drive machineries, and feeding concentrated foodstuffs to livestock and the resultant bulk of waste matter, is the release of excessive and critical amount of greenhouse gases to the environment. Livestock waste matter is both beneficial and harmful depending on the method of disposal and handling. In specialized and intensified livestock production systems where the waste matter is disproportionately high, the fermentation and decomposition processes release excessive greenhouse gases to the atmosphere and leach away nitrogen-containing compounds to water systems polluting and degrading the environment. For example, of the 208000 tons of ammonia emitted in the Netherlands in 1993, 181000 tons originated from manure [4]. 
About $50 \%$ of the nitrogen applied as fertilizer is lost in the soil, the atmosphere and water bodies causing enormous environmental consequences at local, regional and global levels [5]. Since the beginning of the 20th century, an increase of three to ten folds of nitrate $\left(\mathrm{NO}_{3}\right)$ has been recorded in some water systems close to intensive agricultural enterprises [6]. The level of atmospheric nitrous oxide $\left(\mathrm{N}_{2} \mathrm{O}\right)$ has increased by $20 \%$, from below $270 \mathrm{ppb}$ to more than $320 \mathrm{ppb}$ since the beginning of industrial revolution; with most of the change occurring starting the 1950s [7].

Fertilizer production and use as well as fossil fuel burning have caused the global nitrogen cycle to change [8]. The cumulative effect of the disproportional conversion of fossil energy to fertilizer and to mechanical energy that transport inputs and outputs around the world is an imbalance in the ecosystem [9]. The resultant effect on the environment include increase of atmospheric pollutants (e g. $\mathrm{CH}_{4}, \mathrm{NO}_{\mathrm{x}}, \mathrm{N}_{2} \mathrm{O}$, tropospheric ozone) and $\mathrm{CO}_{2}$ leading to climate change, soil and water acidification, shifts in species composition and loss of biodiversity, and eutrophication in the coastal marine water ecosystem [10].

Inorganic fertilizers such as ammonium sulphate, ammonium nitrate and urea can aggravate the process of acidification on old soils, which have been cultivated for many years. Nitrogen fertilizers produce nitrous and nitric acids $\left(\mathrm{HNO}_{2}\right.$ and $\left.\mathrm{HNO}_{3}\right)$ during the nitrification process in aerobic soils. A long term study (5-10 years) on the effects of nitrogen fertilizers in the soil chemistry in Kenya and West Africa moist Savannah indicated an increase in soil acidity to a level of below pH 5.5 [11].

Nitrogen oxides and nitrous oxides can be released from intensive agriculture to the troposphere and react with water molecules in the presence of sunlight to produce ozone $\left(\mathrm{O}_{3}\right)$. Tropospheric ozone is an important component of smog. If the nitrogen emissions from fertilizers are deposited in terrestrial and aquatic ecosystems, they can cause acidification, eutrophcation and shift in species diversity [12]. Nitrous oxide is the most potent greenhouse gas in trapping heat and contributing to global warming. It is also involved in the destruction of stratospheric ozone, the layer that protects the planet earth from harmful ultraviolet rays.

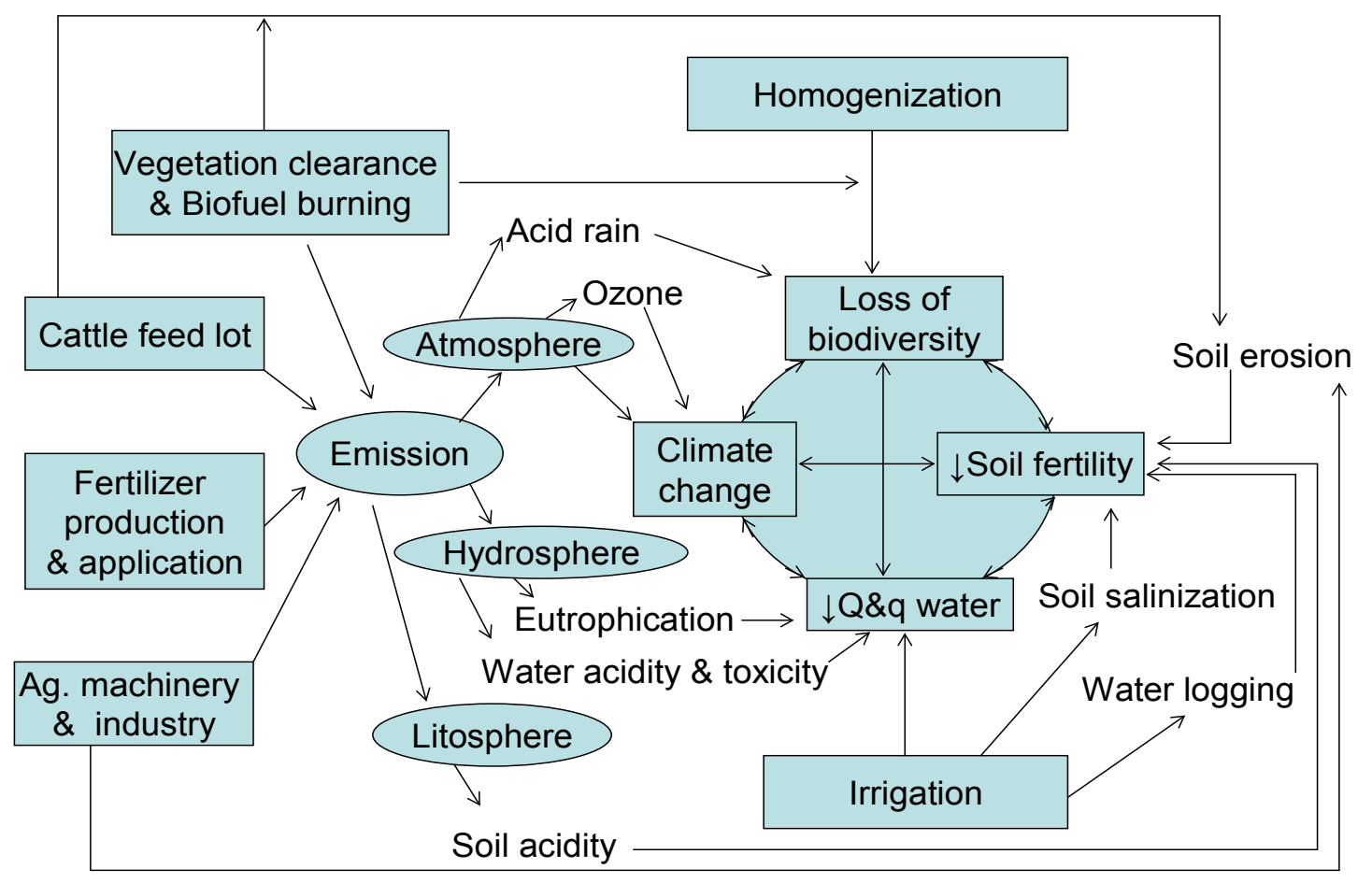

Figure 1: The impact of conventional agriculture practices on the environment

Leaching of nitrate to water systems can increase its concentration in drinking water and downstream surface water system. Since the beginning of the $20^{\text {th }}$ century an increase in the concentration of nitrate in the range of three to tenfold has been recorded in some water systems close to intensive agricultural enterprises [13]. Leaching nitrogen and phosphate fertilizers to estuaries and other coastal marine environment can cause eutrophication resulting in the blooms of nuisance algae, toxic organisms, and anaerobic condition that are lethal to fish [14].

Steady increase in agricultural production to feed the ever growing world population has not only been a function of high yielding varieties, fertilization and pest control but also that of continuous supply of fresh water. At global level, $40 \%$ of agricultural crops are generated from $16 \%$ farmland watered by irrigation systems [15]. Excessive and uncontrolled drawing of irrigation water has lead to water wastage, the decline of underground water and the scarcity in clean and fresh water. In global arid and semiarid areas, uncontrolled irrigation is degrading farm areas due to increased salinization and water logging [15]. 
Trees provide organic substrates, maintain soil structure for air circulation and soil water holding capacity, and control soil erosion. Intensive agricultural practices distract the vegetation, soil life and other essential functions leading to the decline in soil organic matter or soil carbon. In agricultural areas of temperate zone the soil carbon declined by about $50 \%$ in the last 25 years, the loss in tropical area is more dramatic [6]. Consequently, the soil fertility, water holding capacity and carbon dioxide sink are declining.

High yielding crop varieties are often vulnerable to environmental stresses associated not only to climate change, but also to pest and disease invasion. Some industrial chemicals are applied commonly to control the invasion. The chemicals used for this purpose can destroy beneficial insects. Sometimes resistant harmful pests flourish and destroy the main crops. The loss of biodiversity attributable to these practices can result in the disruption of the ecosystem services including pollination, water retention, nutrient cycle and climate regulation [16].

\section{Implications to nutritional security}

As the soil $\mathrm{pH}$ decreases below 5.5, the availability of soil aluminium and manganese increases and reach a level of toxicity, which restricts plant root growth and functions, reducing the uptake of nutrients and water [17]. At similar low soil pH, phosphorus reacts with soil minerals such as iron oxide rendering it unavailable for root uptake. Aluminium toxicity and phosphorus deficiency, which can be inflicted by inorganic fertilizers, constrain crop production in acidic soils [18]. A quantitative evidence on the impact of soil acidity on crop yield is not known, but some controlled experiment on the effects of the treatment of acid soils with lime and triple super phosphate in combination with living mulch showed about three-fold increase in yield [19].

Microbial activity in the soil and in water, produce nitrogen oxides as the result of normal nitrogen cycle. Human activities, including the spread of slurry, the application of N-fertilizer, the combustion of fossil fuel and bio-fuel for energy generation release nitrogen oxide. These anthropogenic activities bring the nitrogen cycle out of balance and result in the accumulation of nitrogen oxides in the troposphere. In the presence of sun light, the nitrogen oxides react to produce ozone. Since the industrial revolution, the ozone concentration in the troposphere has increased by two to three folds [20]. Ozone induces early senescence and abscission of leaves, reduces stomata aperture deceasing carbon uptake or photosynthetic carbon fixation, reduces transport capabilities via phloem decreasing the translocation of nutrients to edible plant parts (grains, fruits, pods, roots), and decreases the ability of some genotypes to withstand climate stresses. As a result, ground-level ozone pollution is already decreasing global crop yields by $\sim 4 \%$ for maize, $\sim 10 \%$ for wheat and $\sim 12 \%$ for soybean [21]. The global crop loss in 2000 due to ozone is estimated at 79-121 Mt, worth US\$11-18 billion [22]. This effect is not local to where ozone is emitted, but it spreads across the continents. On global scale, the pollution from South East Asia imposes the biggest impact causing the loss of about 6.7 million tonnes of wheat and 11.6 million tonnes of rice each year [23].

High-level fertilizer application for boosting agricultural productivity can result in the eutrophication of water bodies and decline in seafood harvest. People are producing increasingly more reactive nitrogen and phosphorus in their daily activity and they induce the in flux of these nutrients to the coastal water at a rate that far exceeds their natural production [24]. This stimulates the fast growth of phytoplankton with the effect that less light penetrates the water body reducing the growth of macro algae and sea-grass, which reduce feed availability, shelter and reproduction provision for small water animals. At the same time, the oxygen availability declines and worsens the negative effect. The cumulative outcome is reduced fish population below and possibly above the oxycline. In addition, some harmful species (marine microalgae and heterotrophic dinoflaglates) bloom in the water body due to eutrophication and can prove lethal to fish, or can have sub-lethal and chronic impacts to both fish and human health. Depressed feeding, impaired reproduction and weak immunity are some of the pervasive effects [25]. Eutrophication is likely to be aggravated where river discharge and fertilizer use increase [26].

Advances in agricultural technology enabled the production of surplus cereals that can more than satisfy the food energy requirement of the global population. Even though it has been possible to reduce hunger in many countries, about one billion people are still chronically underfed because of the limitations in physical, economic and social access to food [27]. At the same time, the availability of disproportionally high amount of cereals is implicated in the nutrition transition phenomenon characterised by simplified diets and lack of dietary diversity. All leading to what is now known as the double burden of nutrition, which in one part is characterised by overweight and obesity and on the other part with micronutrient deficiency. The fundamental cause of overweight and obesity is energy imbalance between calories consumed and calories expended. Globally there has been increased intake of energy dense-diets that are high in soluble carbohydrates and fat $[28,29]$. The consumption of increasing level of food and meat since 1960s [30-32] as well as sedentary life style can be implicated in obesity epidemic. According to USDA (2001) [33], the Americans consumed $530 \mathrm{kcal} / \mathrm{capita} /$ day more food in the beginning of the $21^{\text {st }}$ century than in 1970 ; and that of 1970 was more than that of 1950 .

The overdependence on only a few cereal species for food, particularly in the developing world, caused the neglect and loss of a variety of nutrient rich foodstuffs including livestock products, leading to the spread of micronutrient deficiency problems. Micronutrient malnutrition is an extensive health problem that can be linked to the lack of dietary diversity [34-36] Over two billion people mostly poor women, infants and children, who consume inadequate food, low in diversity including lack of livestock products, are iron, iodine and/or vitamin A deficient; several other micronutrients including zinc, selenium, riboflavin, ascorbic acid and cyanocobalamin are limiting in the diets of a vast number of people in many regions of the world [37]. The puzzling nutritional issue in the world of today is the coexistence of malnutrition (under nutrition) and over nutrition. 


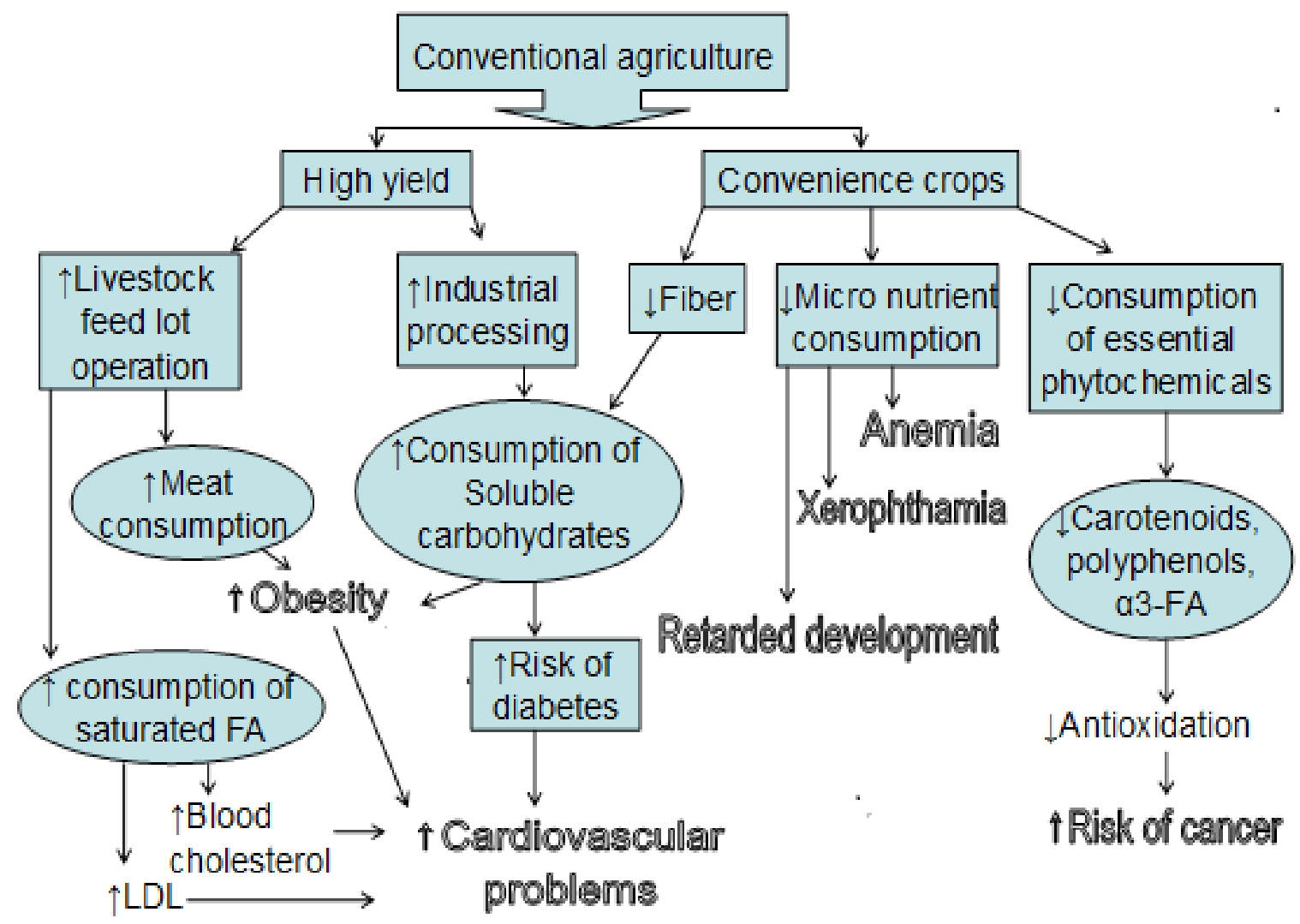

Figure 2: Nutritional health implications of conventional agriculture

\section{Health implications}

The application of inorganic fertilizers to soils could substantially increase crop yield and curve some of the hunger and micronutrient deficiency problems, particularly in the poor regions of the world. Improvement in the dietary situation could additionally strengthen the immune system against parasitic and infectious diseases. The challenge is, however, fertilization imposes changes to nutrients cycle and affects human health well beyond the associated benefits of increased production.

Much of the grain production resulting from conventional agriculture is used for livestock feed and the industrial production of food with intensified soluble carbohydrates. At the same time there has been some increase in both food and meat consumption at regional and global level [30,31] Even though there are some conflicting views, overconsumption could have contributed to the recent development in overweight, obesity, heart and type 2 diabetes problems [38]. Some associate the health problems to the nature rather than to quantity of fat by stating that substituting unsaturated fat for saturated fat can prevent cardiovascular diseases [15]. Some others indicate that the intake of fat including unsaturated fat has been linked to higher risk of type 2 diabetes, but the association is BMI and age dependent [39]. In general, though many hold saturated fatty acids (like the fat from animal origin) as risk factors for cardiovascular diseases, some recent studies have produced conflicting results [40]. It is, however, important to note that, the lipids in the muscles of ruminants, though dependent on the animal diet, often consist of higher proportion saturated fatty acids which are supposed to be risk factors for cardiovascular diseases in humans [41-43].

In conventional agriculture, locally available traditional foodstuffs are replaced by easy to prepare crops such as rice, wheat, maize and potatoes $[36,44]$. Nutrient rich sorghum, millet, wild rice, which involve lengthy preparation and cooking, as well as pulses and vegetables are neglected. As diverse as they are, diets that consist of traditional foodstuffs can cover the requirements for essential micronutrients (vitamin A, Fe, Zn and folic acid) and their bulk minimizes energy concentration and the risk of obesity, cardiovascular problems, diabetes and cancer. The lack of diversity including livestock products is linked to the deficiency of vitamin $\mathrm{A}, \mathrm{Fe}$ and $\mathrm{Zn}$ [45]. Low intake of green and yellow vegetables and fruits [46,47] is associated with inadequate intake of carotenoids, non-nutrient phytochemicals or dietary polyphenols and omega- 3 fatty acids. These are associated with reduced risks of cancer and the antioxidant property that protect the body against other chronic diseases (cardiovascular diseases, diabetes, and macular degeneration as well as neurodegenerative disorders) [48-51]. With the reduction in agricultural and dietary diversity, the availability and accessibility of spices decline irrespective of their antioxidant and insulin modulating property with anti-diabetic, anti-inflammatory, anti-mutagenic and anti-carcinogenic effects $[52,53]$. 
Anthropogenic activity leading to increased emission of nitrogen oxides results in the pollution of atmospheric air and drinking water to a level that results in public health problem. High concentration of nitrogen oxides in the atmosphere $\left(>40 \mathrm{mcg} / \mathrm{m}^{3}\right.$ which is the European standard for the protection of human health) or long-term exposure to lower concentration can affect the respiratory system [54]. In this regard, Kampa and Castanas [55] mentioned that symptoms of nose and throat irritation could follow the exposure to increased level of nitrogen oxide. Nitrogen oxides can also increase the susceptibility to respiratory infection in that they decrease the activity of alveolar macrophages that are significant in preventing pneumonia [56]. In addition, they can cause lung damage through peroxidation of membrane lipids or lipoproteins, each of which increases cell permeability, leading to inflammatory injury. Especially in young children, domestic nitrogen oxides can stimulate asthmatic reaction leading to broncho-constriction [57].

Information about the global groundwater nitrate status is scanty, but high concentration in groundwater with potential serious health consequences is widespread across EU [58]. Agricultural activity counts to the major source of the pollution; in England, for example over $70 \%$ of the surface and groundwater $\mathrm{NO}_{3}$ originate from such activities [59]. In developing countries, the possibility of ground water pollution can be associated with increasing fertilizer application. The potential for pollution in irrigated soils of Asia and humid tropics of Africa is high especially if the efficiency of $\mathrm{N}$-fertilization is poorly managed [60].

Atmospheric nitrogen reacts naturally with rainwater to form nitrate and ammonium ions, which are absorbable and utilisable by plants. Nitrate is common nitrogenous compound that belong to a balanced nitrogen cycle. However, anthropogenic sources such as the application of nitrogen rich fertilizers and concentrate animal feeding operations increase its concentration in groundwater [61]. Levels of nitrates in groundwater in some cases reach a level that exceeds the maximum limit (10ppm nitrate $\mathrm{N}$ maximum limit for safe drinking water, or 45ppm nitrate) proposed by EPA [62] and poses a threat to public health.

The major public health problems that can be associated to the contamination of groundwater with excessive nitrate include methaemoglobinia, reproductive disorders and cancer. Health hazards of consuming water that is contaminated with nitrate are related to the toxicity of nitrite, a molecule that can oxidize haemoglobin to methaemoglobin, a derivative with poor affinity to oxygen. Methaemoglobinia is especially common among infants ("blue-baby syndrome"). In normal conditions, the methaemoglobin is destructed by naturally occurring enzyme the methaemoglobin-reductase. However, this enzyme is not active enough in infants until the end of the first 6 months of age. As a result, infants and young children are more sensitive to nitrate toxicity. In places like India the risk of methaemoglobinia is high because the nitrate concentration in water is more than the minimum contamination level [63].

Conclusive evidence regarding the human reproductive effects of nitrate toxicity is not available. But some research on animals has depicted that toxic level of nitrate in drinking water can cause abortion, intrauterine growth restriction and birth defects [64]. The mechanism by which nitrate/nitrite influence the fetus is not clear particularly in view of the difficulty of mothers' methaemoglobin to cross the placenta. Some suggest that nitrate or its reduced form nitrite may pass to the fetus through an active transport system and the fetal nitrate plasma level may exceed that of the mother [65]. In any case, in-vitro studies revealed that nitrite oxidizes cord blood haemoglobin to methaemoglobin at a rate 5 to 6 fold greater than that of adult blood [65].

There is conflicting information about the carcinogenicity of nitrate or nitrite. Some are convinced that several types of cancer are associated with long time high nitrate intake [67,68]. Nevertheless, others doubt the involvement of the molecules in the aetiology of cancer neither in adults nor in infants [69-71]. Some argue, however, nitrates stimulate endogenous formation of $\mathrm{N}$-nitrosamines, a group of compounds strongly implicated in cancer risk [72].

High-level anthropogenic nitrogen oxides react with atmospheric oxygen in the presences of sunlight to produce tropospheric ozone (O3). Tropospheric ozone is global air pollutant and an important greenhouse gas, with pervasive impacts on human health and the environment. Harmful levels of tropospheric ozone are shown in Table 1. Exposure to harmful levels of ambient ozone is associated with reduced lung function, exacerbation of asthma and premature mortality [73].

\begin{tabular}{|c|c|c|}
\hline \multicolumn{3}{|c|}{ Ozone concentration (ppm) } \\
\hline 8 hours average & AQI & Air quality descriptor \\
\hline $0.0-0.064$ & $0-50$ & Good \\
\hline $0.065-0.084$ & $51-100$ & Moderate \\
\hline $0.085-0.104$ & $101-150$ & $\begin{array}{c}\text { Unhealthy for sensitive } \\
\text { groups }\end{array}$ \\
\hline $0.105-0.124$ & $151-200$ & Unhealthy \\
\hline $0.125-0.404$ & $201-300$ & Very unhealthy \\
\hline
\end{tabular}

Table 1: Air quality index (AQI) for ozone by EPA

\section{Source: EPA $2008[74,75]$}

Some controlled laboratory studies indicated that lung function decreased after exposure to high level of ozone (160 - $700 \mathrm{mcg} /$ $\left.\mathrm{m}^{3}\right)$, even though a lower level $\left(<120 \mathrm{mcg} / \mathrm{m}^{3}\right)$ could also influence the lung function when the body is stressed by increased physical activity such as cycling [76]. 
Despite the efforts to control tropospheric ozone, its concentration has more than doubled to 35 - 40 ppb since the industrial revolution. In some areas of Latin America, North America, Europe and Africa peak values tend to trespass the WHO guideline value of $50 \mathrm{ppb}[77]$.

The imbalance in nitrogen cycle, which results in the increase of nitrogen concentration in surface water, is associated with some vector borne diseases. In this regard, Townsend et al [78] have produced some evidences that show positive correlation between nitrogen concentration in surface water and the larval abundance of malarial mosquitoes (Anopheles sp) as well as the carriers of La Crosse encephalitis and West Nile virus.

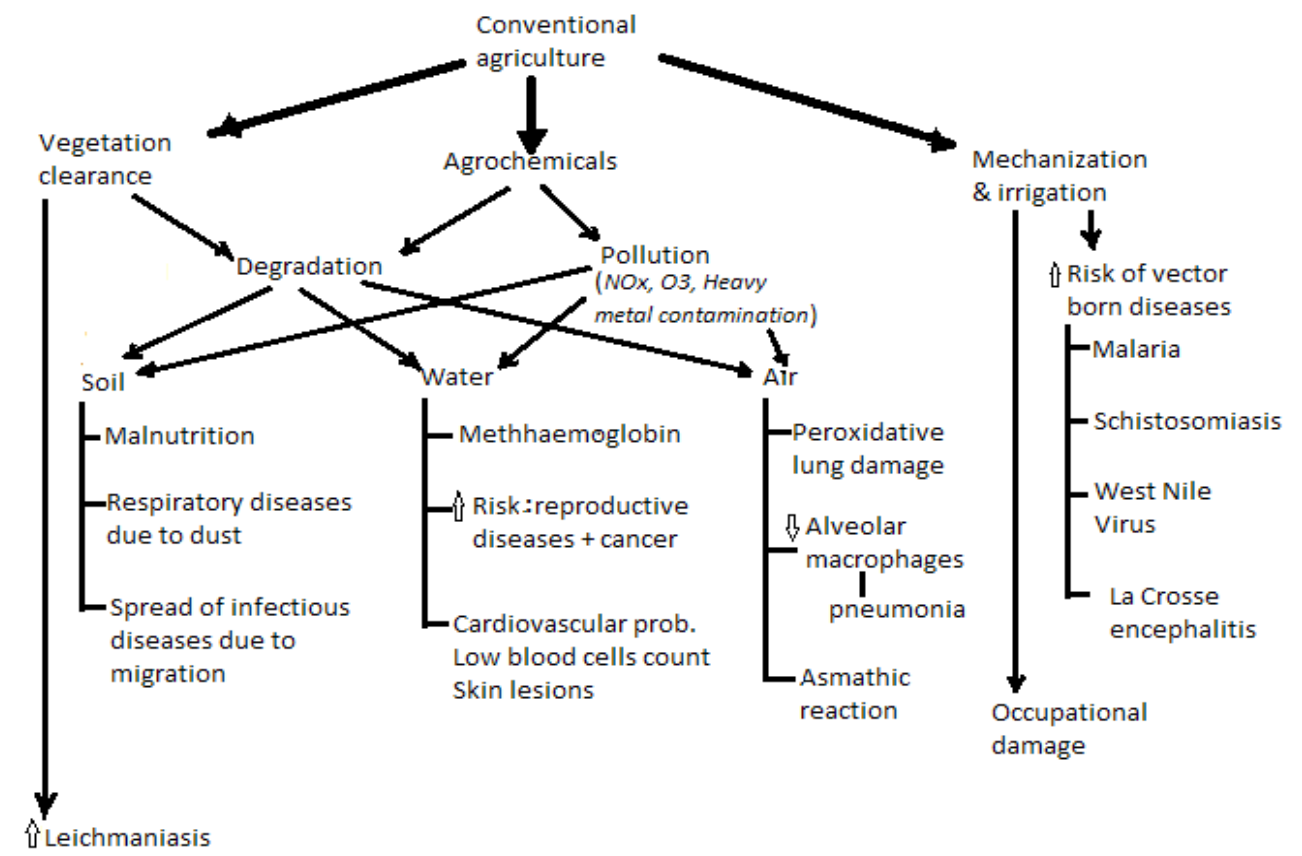

Figure 3: Toxic and infectious health implications of conventional agriculture

The problems of nutrition security and health, that are associated with conventional agriculture, as well as the contexts in which the challenges are to be tackled, are so complex that simple tailor-made solutions are unlikely to function sustainably. Two-system approach that deal separately and/or simultaneously with global, regional and local more impacting issues could produce good results. The global approach can consider green-house-gas emission, climate change and related impacts such as earth warming, desertification and over-flooding. The local approach can deal with soil erosion, contamination, underground water depletion, surfaces water pollution, vegetation clearance and loss of biodiversity in microenvironment with special attention to their role as carbon-sink and micronutrient suppliers, and associated problems of nutrition insecurity and human diseases. Both of the approaches analyze the environment and the ecosystems at different scopes; they design management programs that focus on the restoration and conservation of the ecosystems; improve the human nutrition and health status; develop technologies that could curve the problems in a sustainable manner; and establish monitoring and control mechanisms that functions regularly. Even though the global and local systems approach differ in some way, they synergize and support each other in order to reach similar goals of attaining sustainable nutrition security, human health improvement and environment maintenance.

\section{Conclusion}

In view of the lack of sustainability of conventional agriculture and its negative environmental, nutritional and health implications, the revision of the current food production systems becomes imperative. The challenges for scientists, policy makers and their institutions lie not only in the fight against hunger and "hidden hunger" but also most importantly in the search of suitable and sustainable links between agriculture, nutrition and human health. In this regard, the role of agricultural biodiversity, particularly in the maintenance of the balance of the nutrient cycle, biological-energy-equilibrium, and the well-being of the environment, human nutrition and health can prove indispensable.

\section{References}

1. FAO. FAOSTAT. Food balance sheet accessed 14.02.13.

2. Burney JA, Davis SJ, Lobell DB (2010) Greenhouse gas mitigation by agricultural intensification. PNAS 107: $12052-7$.

3. FAOSTAT 2014. Food Balance Sheet (2011) accessed 12.02.15

4. Steinfeld H. Livestock - Environment Interaction in Industrial Production System. Animal production and Health Division, FAO, Rome; Italy

5. Breemen VN, Boyer EW, Goodale CL, Jaworski NA, Paustian K, et al. (2002) Where did all the nitrogen go? Fate of nitrogen inputs to large watersheds in the north-eastern U.S.A. Biogeochemistry 57/58: 267-93.

6. Matson PA, Parton WJ, Power AG, Swift MJ (1997) Agriculture intensification and ecosystem properties. Science 277: 504-9. 
7. Sanders R (2012) Fertilizer use is responsible for increase in nitrous oxide in atmosphere. News Centre. U C. Berkeley. California accessed 06.03.13.

8. Galloway JN, Dentener FJ, Capone DG, Boyer EW, Howarth RW, et al. (2004) Nitrogen cycle: past, present and future. Biogeochemistry 70: 153-226.

9. Mae Wan Ho (2008) The Rainbow and the Worm: The Physics of Organisms. 3rd ed, World Scientific Publishing Company 97-108.

10. Vitousek PM, Mooney HA, Melillo JM (1997) Human domination of earth's ecosystems. Science 277: 494-9.

11. Smaling EMA, Braun AR (1996) Soil fertility research in Sub-Saharan Africa: New Dimensions, New challenges. Com Soil Sci and Plt Ana 27: 365-86.

12. Bouman AF, Vuuren VDP, Derwent RG, Posch M (2002) Global Analysis of Acidification and Eutrophication of Terrestrial Ecosystems. Water, Air and Soil Pollution 141: 349-82.

13. Howarth RW, Marino R (2006) Nitrogen as limiting nutrient for eutrophication in coastal marine ecosystems: Evolving views over three decades. Limnol Oceanography 51:364-7.

14. Paerl HW (1988) Nuisance phytoplankton blooms in coastal, estuarine and inland waters. Limnol Oceanography 33: 823-47.

15. Hu FB, Willet WC (2002) Optimal diets for prevention of coronary heart disease. JAMA 288: 2569-78.

16. Thrupp LA (2000) Linking agricultural biodiversity and food security: the valuable role of agro-biodiversity for sustainable agriculture. International Affaires 76: 265-81.

17. Kansas State University (2013) The role of nitrogen fertilizer in soil pH levels.

18. Zheng SJ (2010) Crop production on acid soils: overcoming aluminium toxicity and phosphorus deficiency. Ann Bot 106: 183-4.

19. Uexküll VHR, Mutert E (1995) Global extent, development and economic impact of acid soils. Plant and Soil 171: 1-15.

20. Vingarzan R (2004) A review of surface ozone background levels and trends. Atmospheric Environment 38: 3431-42.

21. ilkinson S, Mills G, Illidge R, Davies WJ (2011) How is ozone pollution reducing our food supply? J Experimental Botany 1-10.

22. Avnery S, Mauzerall DL, Liu G, Horowitz LW (2011) Global crop yield reductions due to surface ozone exposure: 1 Year crop production losses and economic damage. Atmospheric Environment 45: 2297-309.

23. SEI (2012) Ozone pollution damage crops across the world. Stockholm Environment Institute.

24. Cloern JE (2001) Our evolving conceptual model of the coastal eutrophication problem. Marine Ecology Progress Series 210: 223-53.

25. Burkholder JM (1998) Implication of Harmful Microalgae and Heterotrophic Dinoflagellates in Management of Sustainable Marine Fisheries. Ecological Applications 8: S37-S62.

26. Rabalias NN, Turner RE, Diaz RJ, Justic D (2009) Global change and eutrophication of coastal waters. J Mar Sci 66: 1528-37.

27. WFP (2009) Fighting Hunger Worldwide. News: Number of world's hungry tops a billion. World Food Program 2009.

28. WHO.2015. Obesity and overweight. Fact sheet No 311, updated January 2015.

29. Swinburn BA, Caterson I, Ssidell JC, James WPT (2004) Diet Nutrition and the prevention of excess weight gain and obesity. Public Health Nutrition. 7: 123146.

30. WHO (2003) Global and regional food consumption patterns and trends. World Health Organization accessed 12.02.15

31. FAO (2003) Global and regional food consumption patterns and trends.

32. Lazar MA (2005) How obesity causes diabetes: not a tall tale. Science 21: 307: 373-5.

33. USDA (2001) Profiling Food Consumption in America. Agricultural Fact Book Chapter 2: 14-5.

34. Grivetti LE, Ogle BM (2000) Value of traditional foods in meeting macro- and micronutrient needs: the wild food connection. Nutr Res 13: 31-46.

35. Chakra Arty I (2000) Food-based strategies to control vitamin A deficiency. Food Nutr Bull 21: 135-43.

36. WHO (2000) Nutrition for health and development: A global agenda for combating malnutrition. World Health Organization 2000. Monograph.

37. Welch R M, Graham R D (1999) A new paradigm for world agriculture: meeting human needs - productive, sustainable, nutritious. Food Crops Research 60: $1-10$.

38. ADA (2010) Diagnosis and Classification of Diabetes Mellitus. American Diabetes Association. Diabetes Care, 33: S62-9.

39. Dam VRM, Stampfer M, Willett W C, Rimm EB, Stampfer MJ, et al. (2002) Dietary fat and meat intake in relation to risk of type 2 diabetes in men. Diabetes Care 25: 417-24.

40. Skeaff CM, Miller J (2009) Dietary fat and coronary heart disease: summary of evidence from the prospective cohort and randomized controlled trials. Ann Nutr Metab 55: 173-201.

41. French P, Stanton C, Lawless F, O’Riordan EG, Monahan FJ, et al. (2000) Fatty composition, including conjugated linoleic acid, of intramuscular fat from steers offered grazing grass, grass silage or concentrate based diets. J Anim Sci 78: 2849-55.

42. Moloney AP, Mooney MT, Kerry JP, Troy DJ (2001) Producing tender and flavoursome beef with enhanced nutritional characteristics. Proc Nutr Soc 60: 22129.

43. Aurousseau B, Bauchart D, Calichon E, Micol D, Priolo A (2000) Effect of grass or concentrate feeding system and rate of growth on triglycerides and phospholipids and their fatty acids in the M. Longissmus Thoracic of lambs. Meat Science 66: 531-641.

44. Smith I F (1995) The case for indigenous West African food culture. UNESCO Breda Series No. 9. Dakar, Senegal: UNESCO Breda.

45. Sommer A, Tarwotjo I, Djunaedi E, West KP, Loeden AA, et al. (1986) Impact of vitamin A supplementation on childhood mortality: a randomized controlled community trial. Lancet 1: 1169-73.

46. WHO (2003) Fruits and Vegetables Promotion Initiative. A meeting report. Geneva.

47. FAO/WHO (2004) Fruits and Vegetables for Health. Report of joint FAO/WHO workshop 1- 3 September, 2014. Kobe, Japan.

48. Kiokias S, Gordon M H (2004) Antioxidant properties of carotenoids in-vitro and in-vivo. Food Rev Intern 20: 99-121.

49. Ojofeitim EO, Adelekan DA, Adeoye A, Ogungbe TG, Imoru AO, et al. (1999) Dietary and lifestyle patterns in the aetiology of cataracts in Nigerian patients. Nutr Health 13: 61-8.

50. McDermoth JJ (2000) Antoxidant nutrients: current dietary recommendation and research update. J Am Pharm Assoc 40: 785-99.

51. Johnson IT, Williamson G, Musk SRR (1994) Anticarcinogenic factors in plant foods: a new class of nutrients? Nutr Res Rev 7: 175-204. 
52. Kelble A (2005) Spices and type 2 diabetes. Nutr Food Sci 35: 81-7.

53. Srinivasan K (2005) Role of spices beyond food flavouring: neutraceuticals with multiple health effects. Food Rev Intern 21: 167-88.

54. CIWEM (2009) Nitrogen Dioxide Concentration in the Atmosphere. Chartered Institution of Water and Environment Management, 15 John Street, London, WCIN 2EB.

55. Kampa M, Castanas E (2008) Human health effects of air pollution. Environ Pollution 151: 362-67.

56. Chauhan AJ, Kishna MT, Frew AJ, Holgate ST (1998) Exposure to nitrogen oxide $\left(\mathrm{NO}_{2}\right)$ and respiratory disease risk. Rev Environ Health 13 : 73-90.

57. Patz JA, Daszak I, Tabor GM (2004) Unhealthy landscapes: policy recommendations on land use change and infectious disease emergence. Environ Health Persp 112: 1092-98.

58. EEA. European Environmental Agency. Groundwater quality and quantity in Europe- Data and basic information. Technical report $22 / 1999123$.

59. Kraft GJ, Browne BA, Vita DWM, Mechenich D J (2008) Agricultural pollution penetration and steady state in thick aquifers. Ground Water 46: 41-50.

60. Singh B, Singh Y, Sekhon GS (1995) Fertilizer-N use efficiency and nitrate pollution of groundwater in developing countries. J Cont Hydrol 20: 167-84.

61. Spadling R, Exner M (1993) Occurrence of nitrate in groundwater. J Environ Qual 22: 392-402.

62. EPA. US Environmental Protection Agency. Drinking Water Contamination.

63. Gupta SK, Gupta RC, Seth AK, Gupta AB, Bassin JK, et al. (2000) Methaemogolobinaemia in areas with high nitrate concentration in drinking water. Natl Med J India 13: 58-61

64. Fan AM, Steinberg VE (1996) Health implication of nitrate and nitrite in drinking water: un update on methaemoglobinaemia occurrence and reproductive and developmental toxicity. Regul Toxicol Pharmacol 23: 35-43.

65. Manassaram DM, Backer LC, Moll DM (2006) A review of nitrates in drinking water: maternal exposure and adverse reproductive and development outcomes. J Environ Health 114: 320-27.

66. Tarburton JP, Metcalf WK (1985) Kinetic of amyl nitrite-induced haemoglobin oxidation in cord and adult blood. Toxicology 36: 15-21.

67. Ward MH, Pan WH, Cheng YJ, Li FH (2000) Dietary exposure to nitrite and nitrosamines and risk of nasopharyngeal carcinoma in Taiwan. Int J Cancer 86: 603-9.

68. Volkmer BG, Ernst B, Simon J, Kuefer R, Bartsch G J, et al. (2005) Influence of nitrite levels in drinking water on urological malignancies: a community based cohort study. BJUI. 95: 972-6.

69. Mueller BA, Narton K, Holly EA, Martin PS (2001) Residential water sources and the risk of childhood brain tumours. Environ Health Persp. 109: 551-6.

70. Rivard IC, Olson E, Jacques L, Avotte P (2001) Drinking water contaminations and childhood leukaemia. Epidemiology 12: 13-9.

71. Law G, Parslow R, McKinney P, Cartwright R (1999) Non Hodgkin's lymphoma and nitrate in drinking water: a study in Yorkshire, United Kingdom. J Epidemiol Community Health. 53: 383-4.

72. Maanen VJS, Welle IJ, Hageman G, Dallinga JW, Mertens PL, et al. (1996) Nitrate contamination of drinking water; relationship with HPRT variant frequency in lymphocyte DNA and urinary excretion of N-nitrosamines. Environ Health Persp 104: 522-8.

73. Lippman M (1993) Health effects of tropospheric ozone: review of recent research findings and their implications at ambient air quality standards. J Expo Anal Environ Epidemiol 3: 103-29.

74. EPA (2008) Air Quality Guide for Ozone. United States Environmental Protection Agency. Air and Radiation Washington D C 20460 EPA - $456 / F$ - 08 - 001 March 2008 accessed 20.03.14.

75. The Royal Society (2008) Ground level ozone in the $21^{\text {st }}$ century: future trends, impacts and policy implication. The Royal Society, Science Policy. 6 - 9 Carlton House Terrace. London SW 1 Y 5AG.

76. Brunekreef B, Hoek G, Breugelmans O, Leentvaar M (1994) Respiratory effects of lower level photochemical air pollution in amateur cyclists. Am J Respir Crit Care Med 150: 962-6.

77. WHO (2005) Air quality guidelines: global update, particulate matter, ozone, nitrogen dioxide and sulphur dioxide. accessed 17.03.14.

78. Townsend AR, Howarth RW, Bazzaz FA, Booth MS, Cleveland CC, et al (2003) Human health effects of a changing global nitrogen cycle. Front Ecol Environ 1: $240-6$.

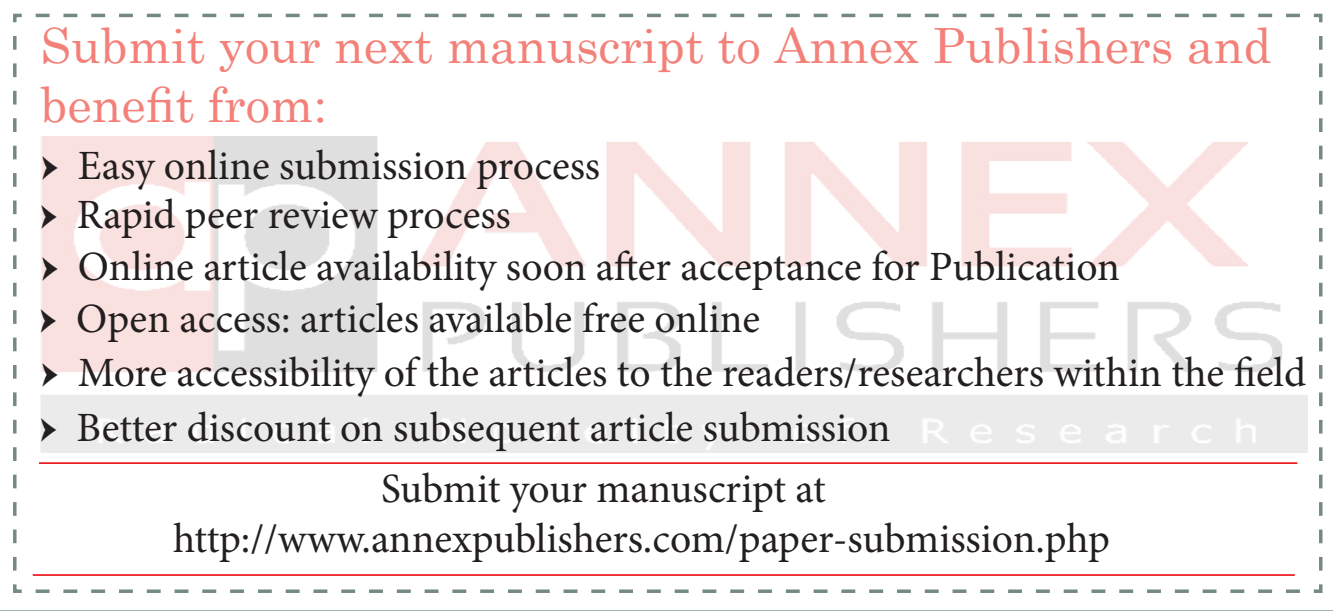

